\title{
PENGUKURAN USABILITY SISTEM OPERASI ANDROID MENGGUNAKAN USE QUESTIONAIRE DI UNIVERSITAS NEGERI MANADO
}

\author{
John Reimon Batmetan,Julita Mamonto, Hizkia Legesan, Zachary Sagai
}

Program studi Pendidikan Teknologi Informasi dan Komunikasi, Universitas Negeri Manado, Tondano. 95318

john.reimon@gmail.com, julitaveronica00@gmail.com, hizzukia@gmail.com, zacharysagai@gmail.com

\begin{abstract}
Abstrak
Aspek- aspek usability dijadikan acuan dalam mengukur tingkat kebergunaan pada system operasi android. Penelitian ini dilakukan di Universitas Negeri Manado, respondennya sendiri meliputi Dosen, staff dan mahasiswa. Penelitian ini menggunakan use questionaire yang memiliki aspek efektivitas, efisiensi dan kepuasan. Dalam pengumpulan data peneliti menggunakan kuesioner dengan jumlah dalam penelitian ini ada 30 responden dengan 13 atribut pertanyaan yang diajukan. Setelah memperoleh data, selanjutnya dilakukan analisa dengan menggunakan metode skala likert untuk memperoleh presentase nilai usability pada system operasi android di Universitas Negeri Manado. Hasil Pengukuran Usability menunjukkan keseluruhan atribut memiliki usability oleh user, rata-rata diatas nilai 3, sehingga dapat dikatakan bahwa system operasi android yang digunakan oleh user telah memiliki nilai aspek Usability yang baik.
\end{abstract}

Kata Kunci : Usability, Universitas Negeri Manado, Use Questionaire, Skala Likert.

\section{PENDAHULUAN}

Android menjadi salah satu sistem operasi yang banyak digunakan di dunia. Sistem operasi berbasis Linux ini, diperuntukkan bagi perangkat seluler seperti telepon pintar dan komputer tablet [1]. Android menyediakan platform terbuka bagi para pengembang untuk menciptakan berbagai macam aplikasi untuk digunakan pada piranti bergerak [2]. Banyaknya pengguna sistem operasi android tentunya dipengaruhi oleh tingkat kegunaan yang dimiliki sistem operasi ini [3].

Usability testing merupakan suatu attribut untuk menilai seberapa mudah sesuatu digunakan[4]. Usability (kegunaan) adalah bagian dari bidang ilmu multi disiplin Human Computer Interaction $(\mathrm{HCl})[1]$. Usability berasal dari kata usable yang memiliki arti dapat digunakan dengan baik [1]. Hal ini mengacu kepada bagaimana pengguna dapat menggunakan sesuatu untuk mencapai suatu tujuan, dan kepuasan mereka dalam penggunaannya [5].
Usability yang tinggi memiliki kaitan erat dengan kepopuleran dan tingginya pemanfaatan sistem atau perangkat lunak oleh pengguna dalam mencapai tujuan mereka[5]. Usability testing memiliki manfaat dalam mengumpulkan umpan balik secara objektif dari kegunaan seperti kepuasan pengguna maupun daari segi interface [4]. Pengukuran usability menurut Ido memiliki beberapa aspek yaitu efisiensi, efektivitas dan kepuasan [1]. Menurut Jacob Nielson (2003) dalam mengemukakan lima aspek usability atau lima atribut usability yaitu : 1) Mudah dipelajari (learnability) Kualitas sistem yang menunjukkan apakah sistem mudah untuk dipelajari dan digunakan dalam menyelesaikan tugas tertentu. 2) Efisiensi (efficiency) Cara yang dapat dilakukan sistem untuk mendukung pengguna dalam melakukan pekerjaannya, memiliki langkah-langkah yang sederhana untuk mendapatkan hasil yang sama. Contoh: oneclick shopping: Amazon.com, 3) Mudah diingat (memorability) Kemampuan sistem untuk mudah diingat, baik dari sisi fitur atau menu-menu yang ada maupun cara 
pengoperasiannya. 4) Kesalahan dan keamanan (errors) Perlindungan dan pertolongan kepada pengguna terhadap kondisi dan situasi yang tidak diinginkan dan berbahaya ketika mengoperasikan sistem, misalnya: menu help untuk memberi solusi, dan konfirmasi penghapusan berkas. 5) Kepuasan (satisfaction) Menunjuk kepada suatu keadaan dimana pengguna merasa puas setelah menggunakan sistem tersebut karena kemudahan yang dimiliki oleh sistem. Semakin pengguna menyukai suatu sistem, secara implisit mereka merasa puas dengan sistem yang dimaksud [6]. Aspek dan kriteria inilah yang akan menjadi acuan dalam penelitian ini.

Penelitian ini bertujuan untuk mengukur bagaimana usability Sistem Operasi Android di Universitas Negeri Manado. Kuesioner yang akan digunakan adalah Use Questionaire yang memiliki beberapa aspek menurut Ido yaitu efisiensi, efektivitas dan kepuasan [1]. Kuesioner ini dibuat dalam bentuk skor lima poin dengan memakai model skala likert . Untuk pengukuran tingkat persetujuan user terhadap statement hasil pengukuran kemudian diolah dengan metoda statistik deskriptif dan dilakukan analisis baik terhadap masing-masing parameter atau terhadap keseluruhan parameter. Respondennya sendiri meliputi Dosen, staff dan mahasiswa yang ada di Universitas negeri Manado.

\section{METODE PENELITIAN}

\section{Populasi dan Sampel}

Populasi merupakan kelompok atau kumpulan individuindividu atau obyek penelitian yang memiliki standarstandar tertentu dari ciri-ciri yang telah ditetapkan sebelumnya[4]. Jumlah responden yang dilibatkan dalam penelitian ini adalah 28 responden dari suatu populasi yaitu dosen, staff karyawan dan mahasiswa yang ada di Univesitas Negeri Manado.

\section{Metode Pengumpulan Data}

Metode pengumpulan data primer dilakukan dengan penyebaran kuesioner melalui google forms untuk memperoleh data. Dalam penelitian ini peneliti menggunakan Skala Likert. Skala likert merupakan suatu skala psikometrik yang paling banyak digunakan dalam riset berupa survey [7]. Skala ini diambil dari nama Rensis Likert, yang menerbitkan suatu laporan yang menjelaskan penggunaan skala ini [8].

Pada saat menanggapi pertanyaan dalam skala Likert, responden menentukan tingkat persetujuan mereka terhadap suatu pernyataan dengan memilih salah satu dari pilihan yang tersedia. Biasanya disediakan lima pilihan skala dengan format seperti: $1=$ Kurang Mudah Sekali. 2 = Kurang Mudah. $3=$ Cukup Mudah. $4=$ Mudah 5 = Sangat Mudah

Untuk mendapatkan data yang bersifat ordinal dan diberi skor sebagai berikut :

Tabel.1 Bobot Nilai

\begin{tabular}{cccccc}
\hline PK & KMS & KM & CM & M & SM \\
\hline 1 & 2 & 3 & 4 & 5 \\
\hline
\end{tabular}

Keterangan :

PK : Pertanyaan Kuesioner

KMS : Kurang Mudah Sekali

KM : Kurang Mudah

$\mathrm{CM}$ : Cukup Mudah

$\mathrm{M}$ : Mudah

SM : Sangat Mudah

Pada penelitian ini, langkah awal yang dilakukan adalah dengan mengidentifikasi masalah, selanjutnya dilakukan studi awal/studi pustaka terkait dengan Usability Testing.

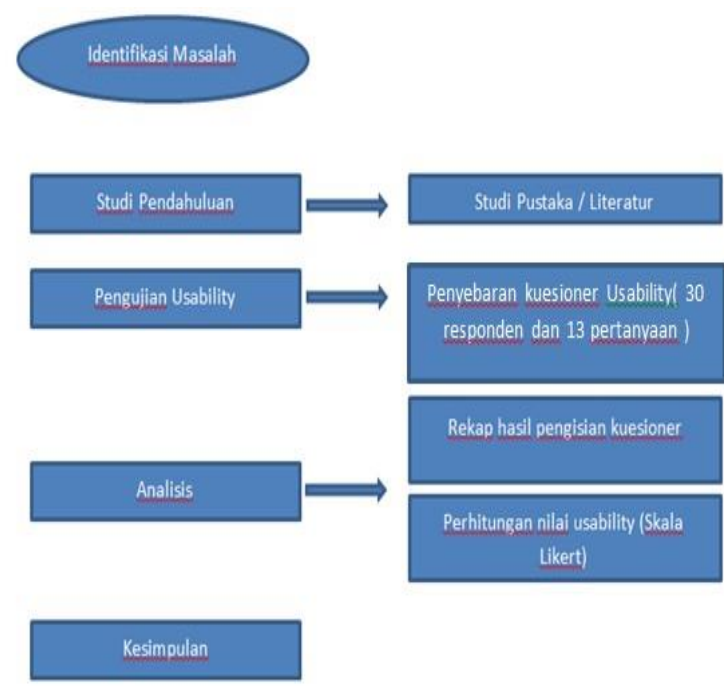

Gambar 1. Alur Metode Penelitian 


\section{HASIL DAN PEMBAHASAN}

Dalam penelitian ini, peneliti membagikan kuesioner kepada dosen, staff karyawan, dan mahasiswa di Universitas Negeri Manado yang berisi 13 pertanyaan yang sudah mewakili kelima aspek usability dengan menggunakan media google forms. Pengguna mengisi kuesioner yang sudah dibagikan berdasarkan pengalamannya (apa yang dilihat dan dirasakan) pada saat menggunakan system operasi android. Setiap pertanyaan dari kuesioner tersebut memiliki tujuan untuk mengukur tingkat usability menurut penerimaan user, yang selanjutnya akan di nilai menggunakan skala Likert. Pertanyaan tersebut telah mewakili kelima aspek Usabillity, diantaranya yaitu learnability, eficiency, memorability, errors, dan satisfaction [1].

Dari kuesioner yang telah diberikan kepada responden, data dianalisa menggunakan model skala likert.

\section{Rumus Index \% = Total Skor $/$ Y x 100}

$\mathrm{Y}=$ Skor tertinggi likert $\mathrm{x}$ jumlah responden (Angka Tertinggi 5) "Perhatikan Bobot Nilai"

$\mathrm{X}=$ Skor terendah likert $\mathrm{x}$ jumlah responden (Angka Terendah 1) "Perhatikan Bobot Nilai"

Tabel 2. Presentase Nilai

Tabel 2. Presentase Nilai
\begin{tabular}{|l|l|}
\hline \multicolumn{1}{|c|}{ Jawaban } & \\
\hline $0 \%-19.99 \%$ & Kurang Mudah sekali \\
\hline $20 \%-39.99 \%$ & Kurang Mudah \\
\hline $40 \%-59.99 \%$ & Cukup Mudah \\
\hline $60 \%-79.99 \%$ & Mudah \\
\hline $80 \%-100 \%$ & Sangat Mudah \\
\hline
\end{tabular}

Jumlah skor tertinggi untuk item SANGAT MUDAH ialah $5 \times 30=150$, sedangkan item KURANG MUDAH SEKALI ialah $1 \times 30=30$. Jadi, jika total skor responden di peroleh angka 150, maka penilaian interpretasi responden terhadap Sistem operasi Android tersebut adalah hasil nilai yang dihasilkan dengan menggunakan rumus Index \%.

\section{Analisa Usability}

Setelah penyebaran kuesioner yang diberikan kepada 30 responden,maka selanjutnya dilakukan rekap terhadap hasil kuesioner yang diperoleh.

Tabel 2. Rekap Nilai Usability

\begin{tabular}{|c|c|c|c|}
\hline NO & Pertanyaan & $\begin{array}{c}\text { Presentase } \\
\text { Nilai }\end{array}$ & Keterangar \\
\hline 1. & Apakah tampilan Android mudah dikenali? & $84 \%$ & SM \\
\hline 2. & Apakah android mudah dioperasikan..? & $82 \%$ & SM \\
\hline 3. & $\begin{array}{l}\text { Apakah tampilan warna pada android bagus dilihat \& } \\
\text { tidak membosankan..? }\end{array}$ & $77,3 \%$ & M \\
\hline 4. & $\begin{array}{l}\text { Apakah tampilan menu dalam android mudah } \\
\text { dikenali..? }\end{array}$ & $80,6 \%$ & SM \\
\hline 5. & Apakah aplikasi halaman android mudah dicari..? & $79,3 \%$ & M \\
\hline 6. & Apakah aplikasi yang ada mudah dibaca..? & $82 \%$ & SM \\
\hline 7. & $\begin{array}{l}\text { Apakah aplikasi yang dibutuhkan mudah } \\
\text { didownload..? }\end{array}$ & $77,3 \%$ & M \\
\hline 8. & Apakah simbol-simbol gambar mudah dipahami..? & $74 \%$ & M \\
\hline 9. & $\begin{array}{l}\text { Apakah mudah mengakses informasi produk yang } \\
\text { ditawarkan..? }\end{array}$ & $77,3 \%$ & M \\
\hline 10. & $\begin{array}{l}\text { Apakah spesifikasi produk yang ditawarkan sesuai } \\
\text { dengan kebutuhan.? }\end{array}$ & $68 \%$ & M \\
\hline 11. & $\begin{array}{l}\text { Apakah aplikasi transaksi pembayaran yang tersedia } \\
\text { mudah diakses..? }\end{array}$ & $67,3 \%$ & M \\
\hline 12. & $\begin{array}{l}\text { Apakah akses informasi pada setiap halaman sudah } \\
\text { terjamin keamanannya..? }\end{array}$ & $60,6 \%$ & M \\
\hline 13. & $\begin{array}{l}\text { Apakah menu dan tampilan halaman android mudah } \\
\text { diingat..? }\end{array}$ & $80 \%$ & SM \\
\hline
\end{tabular}

Pada table diatas menunjukan nilai kepuasan/penerimaan user (acceptance) terhadap tiap butir pertanyaan yang diajukan. Dapat dilihat bahwa untuk "tampilan android mudah dikenali" memiliki presentase nilai 84\% (sudah berada diatas 3 / diatas nilai tengah) dalam skala likert. Ini dapat diartikan bahwa system operasi android mudah dikenali oleh pengguna dari segi interface.

Jika disesuaikan dengan masing-masing aspek usability pada table 2, data dikatakan bahwa Sistem operasi Android telah memiliki nilai usability yaitu, learnability, efficiency, memorability, errors, satisfaction yang sangat baik. Hal ini ditunjukkan dengan nilai hasil usability pada lima atribut sebagai berikut

a. Nilai atribut "Kemudahan interface android dikenali" sebesar $84 \%$ yang menunjukkan bahwa android telah memiliki nilai aspek Learnability. 
b. Nilai atribut "Kemudahan android untuk dioperasikan" sebesar $82 \%$ menunjukkan bahwa Android telah memiliki nilai aspek Efficiency.

c. Nilai atribut "Kemudahan mengingat kembali menu dan tampilan pada Android" sebesar $80,6 \%$ menunjukkan bahwa Android telah memiliki nilai aspek Memorability.

d. Nilai atribut "Kemudahan aplikasi android yang ada mudah dibaca" sebesar $82 \%$ dan atribut "Simbolsimbol gambar mudah dipahami" sebesar 74\% membuat Android dapat dikatakan telah meminimalisasi aspek Errors.

e. Dan dari keseluruhan atribut yang memiliki nilai rata-rata di atas 3, menunjukkan jika Android telah mempunyai aspek Satisfaction yang baik.

\section{KESIMPULAN}

Hasil Pengukuran Usability menunjukkan keseluruhan atribut memiliki usability oleh user, rata-rata diatas nilai 3, sehingga dapat dikatakan bahwa system operasi android yang digunakan oleh user telah memiliki nilai aspek Usability dan banyak digunakan oleh kalangan dikarenakan android sangat mudah dipelajari serta dimengerti oleh pengguna. Hasil penelitian yang menunjukkan bahwa Sistem Operasi Android telah memiliki aspek Usability, maka diharapkan pengguna dapat memanfaatkan system operasi ini dengan lebih baik lagi, untuk mempermudah dalam menunjang kegiatan sehari-hari.

\section{REFERENSI}

[1] D. R. Rahadi, "Pengukuran Usability Sistem Menggunakan Use Questionnaire Pada Aplikasi Android Interface pengguna Android didasarkan pada manipulasi langsung menggunakan masukan sentuh yang serupa dengan tindakan di dunia nyata, seperti menggesek ( swiping ), mengetuk," J. Sist. Inf., vol. 6, no. 1, pp. 661-671, 2014.

[2] V. Fuspita, A. Vatresia, and D. Andreswari, "Sistem Pendukung Keputusan Pemilihan
Restoran Di Kota Bengkulu Dengan Metode Simple Additive Weighting (Saw) Berbasis Sistem Operasi Android," J. Rekursif, vol. 2, no. 1, pp. 4552, 2014.

[3] Y. Nurhadryani and H. Sukoco, "Pengembangan dan Uji Usability Sistem Informasi Manajemen Pemantauan Kehadiran dan Nilai Ujian Siswa," J. Ilmu Komput. Agri-Informatika, vol. 3, pp. 5866, 2015.

[4] A. Zuntriana, "Remote usability testing in portal web Perpustakaan Nasional Republik Indonesia," Rec. Libr. J., vol. 1, no. 1, pp. 68-76, 2015.

[5] D. Nurani, W. W. Winarno, and S. A. Syahdan, "Analisis Usability Pada Aplikasi I-Siska PT . Telkom Yogyakarta," pp. 23-32.

[6] N. L. A. K. Y. Sarja, "Analisis Pengukuran Faktor Usability Sistem Informasi Konferensi Nasional Sistem Dan Informatika Stikom Bali," in Seminar Nasional Teknologi Informasi dan Multimedia, 2016, pp. 6-7.

[7] B. Pudjoatmodjo and R. Wijaya, "Tes Kegunaan (Usability Testing) Pada Aplikasi Kepegawaian Dengan Menggunakan System Usability Scale," in Seminar Nasional Teknologi Informasi dan Multimedia 2016, 2016, pp. 37-42. [8] S. A. Rande and R. A. E. Wijaya, "MENGGUNAKAN SKALA LIKERT."

[8] J. R. Batmetan Suyoto, J. D. C. L. Suares, "An Empirical Investigation on Customer Behavior to Adopt Mobile Commerce among the $Y$ Generation in Indonesia", Sriwijaya International Conference On Engineering, Science \& Technology [SICEST 2016], 2016

[9] J.R. Batmetan, "Algoritma Ant Colony Optimization (ACO) untuk Pemilihan Jalur Tercepat Evakuasi Bencana Gunung Lokon Sulawesi Utara", Jurnal Teknologi Informasi-AITI, 2016, vol.13, no.2, pp 31-48

[10] L. Madeso, D. R. Kabo, J. R. Batmetan, "Rancang Bangun Sistem Pakar Penentuan Status Gizi Pada Balita Menggunakan Metode Forward Chainning", E-Jurnal UNSRIT, vol.2 
[11] J. R. Batmetan, V. R. Palilingan, " Higher Education Students' Behaviour to Adopt Mobile Learning", IOP Conference Series: Materials Science and Engineering, 2018, vol. 306, Issue 1, pp. 012110 (2018)

[12] V. R. Palilingan, J. R. Batmetan, " Incident Management in Academic Information System using ITIL Framework", IOP Conference Series: Materials Science and Engineering, 2018, vol. 306, Issue 1, pp. 012110 (2018)

[13] J. R. Batmetan, A. J. Santoso, Pranowo, " A Multiple-Objective Ant Colony Algorithm for Optimizing Disaster Relief Logistics", Advanced Science Letters, 2017, vol.23, no.3, pp. 2344-2347

[14] M. L. Tompodung, F. Supit, J. R. Batmetan, " Rancang Bangun Aplikasi Sensus Penduduk Berbasis Android", Buletin Sariputra, 2017, vol.7, pp. $57-61$

[15] J. R. Batmetan, " Optimasi Strategi Smart Environment Dalam Mitigasi Bencana Menggunakan Multi-Objective Aco (Mo-Aco) Algorithm", Pasca Sarjana Magister Teknik Informatika Universitas Atma Jaya Yogyakarta, 2016 